\title{
PELATIHAN PEMBUATAN MINYAK VIRGIN COCONUT OIL (VCO) BAGI MASYARAKAT TERDAMPAK BENCANA GEMPA DI DESA DANGIANG KABUPATEN LOMBOK UTARA
}

\author{
Diah Rahmawati'), Alpiana²), Ilham³), Hidayati4), Rima Rahmaniah4) \\ 1)Program Studi Teknik Pertambangan, Fakultas Teknik, Universitas Muhammadiyah Mataram, Mataram, NTB, Indonesia \\ 2)Program Studi Pendidikan Guru Sekolah Dasar, FKIP, Universitas Muhammadiyah Mataram, Mataram, NTB, Indonesia \\ 3)Program Studi Ilmu Pemerintahan, FISIPOL, Universitas Muhammadiyah Mataram, Mataram, NTB, Indonesia \\ 4)Program Studi Pendidikan Bahasa Inggris, FKIP, Universitas Muhammadiyah Mataram, Mataram, NTB, Indonesia \\ Corresponding author : Diah Rahmawati \\ E-mail : dee_rahmawati@gmail.com
}

\section{Diterima 12 November 2020, Direvisi 17 November 2020, Disetujui 17 November 2020}

\begin{abstract}
ABSTRAK
Minyak kelapa murni, atau lebih dikenal dengan Virgin Coconut Oil (VCO), adalah modifikasi proses pembuatan minyak kelapa sehingga dihasilkan produk dengan kadar air dan kadar asam lemak bebas yang rendah, berwarna bening, berbau harum, serta mempunyai daya simpan yang cukup lama yaitu lebih dari 12 bulan. Virgin coconut oil mengandung asam laurat $\mathrm{CH} 3(\mathrm{CH} 2) 10 \mathrm{COOH} 50 \%$ dan asam kaprilat $\mathrm{CH} 3(\mathrm{CH} 2) 6 \mathrm{COOH} 7 \%$. Kedua asam ini merupakan asam lemak jenuh rantai sedang yang mudah dimetabolisir dan bersifat anti mikroba. Di dalam tubuh, asam laurat menjadi monolaurin, sedangkan asam kaprilat menjadi monokaprin (Sutarmi, 2006). Monolaurin adalah monogliserida antiviral, antibakteri dan antiprotozoal yang digunakan oleh sistem kekebalan manusia dan hewan untuk menghancurkan virus-virus pelindung lemak, seperti HIV, herves, influenza berbagai bakteri patogen. Asam kaprat yang juga berfungsi sebagai zat kekebalan tubuh ketika diubah menjadi monokaprin di dalam tubuh manusia atau hewan. Monokaprin memiliki efek antiviral terhadap HIV dan herpen simplex serta bakteri yang tertular melalui hubungan seks (Novarianto, 2007). Berdasarkan hal tersebut, maka dapat dikatakan bahwa minyak ini memiliki banyak manfaat sehingga tim PKM memandang perlu mengadakan pelatihan pembuatan minyak VCO yang diadakan di desa Danging Kabupaten Lombok Utara yang memiliki sumber daya alam yang besar yang merupakan desa terdampak bencana gempa tahun 2018 lalu. Metode observasi partisipatoris atau observasi partisipan dan praktik langsung telah dipergunakan dalam PKM ini dengan melibatkan pula Komunitas Relawan Mataram yang juga tergabung dalam Muhammadiyah Disaster Management Centre (MDMC) Nusa Tenggara Barat. Hasil capaian dan kesimpulan dalam kegiatan ini adalah a. dimilikinya pengetahuan dan pemahaman yang merupakan upaya pemberdayaan bagi para perempuan di desa ini agar memiliki ketrampilan dalam pengolahan kelapa khususnya pembuatan minyak VCO, dan b. memberikan ketrampilan yang lebih akan pemanfaatan sumber daya alam agar menjadi tambahan penghasilan atau mampu meningkatkan pendapatan (income) yang cukup potensial sebagai langkah awal membangun masyarakat yang berdayaguna.
\end{abstract}

Kata kunci: kelapa; minyak VCO

ABSTRACT
Pure coconut oil, otherwise known as Virgin Coconut Oil (VCO), is a modification of the making process
which produces products with low moisture and fatty acid content that is clear, clear in color, smells
good, and has a long shelf life of more than 12 months. Virgin coconut oil contains $\mathrm{CH} 3(\mathrm{CH} 2) 10 \mathrm{COOH}$
$50 \%$ lauric acid and $\mathrm{CH} 3(\mathrm{CH} 2) 6 \mathrm{COOH} 7 \%$ kaprilic acid. Both of these acids are medium-chain saturated
fatty acids that are easily metabolized and anti-microbial. In the body, lauric acid becomes monolaurin,
while kaprilic acid becomes monokaprin (Sutarmi, 2006). Monolaurin is an antiviral, antibacterial and
antiprotozoal monoglyceride used by the human and animal immune systems to destroy fat-protective
viruses, such as HIV, herves, influenza and various pathogenic bacteria. Kaprat acid also serves as an
immune substance when converted into monokaprin in the human or animal body. Monokaprin has
antiviral effects on HIV and herpen simplex as well as bacteria infected through sex (Novarianto, 2007).
Based on this, it can be said that this oil has many benefits, so that the PKM team considers it necessary
to hold vco oil manufacturing training which held in Danging village of North Lombok Regency which
has a large natural resource that is a village affected earthquake by the 2018. Participatory observation
methods or observations of participants and direct practice have been used in this PKM by involving
mataram volunteer community which is also incorporated in Muhammadiyah Disaster Management
Centre (MDMC) West Nusa Tenggara. The results of the achievements and conclusions in this activity 
are a. knowledge and understanding which is an empowerment effort for women in this village to have skills in coconut processing, especially making vco oil, and b. provide more skills for utilization of natural resources in order to be additional or able to increase income that is potential enough as the first step in building a empowered society.

Keywords: coconut; VCO oil.

\section{PENDAHULUAN}

Tanaman kelapa secara komersial dapat tumbuh dengan baik pada ketinggian dari pinggir laut sampai 600 meter di atas permukaan laut. Ketinggian optimal untuk pertumbuhannya $0-450 \mathrm{~m} \mathrm{dpl}$, diatas ketinggian tersebut tanaman kelapa masih dapat tumbuh, namun hasilnya menjadi berkurang. Pada ketinggian $450-1000 \mathrm{~m}$ dpl waktu berbuah terlambat, produksi sedikit dan kadar minyaknya rendah. Di beberapa lokasi dipinggir pantai, banyak kelapa tumbuh dengan baik (Djohana, 1986). Ketinggian tempat tumbuh mempunyai korelasi dengan suhu Setiap kenaikan $100 \mathrm{~m}$ dpl suhu akan turun kirakira 0,60-0,65 OC (Soedarsono, 1985; Jumin, 2002). Oleh karena itu di daerah ketinggian akan mempunyai suhu lebih rendah jika dibandingkan dengan suhu daerah dataran rendah. Perbedaan suhu akan 433 memberikan pengaruh terhadap perubahan faktor iklim lainnya seperti curah hujan, kelembaban, intensitas sinar matahari dan kecepatan angin. Perubahan komponen iklim tersebut secara langsung akan berpengaruh terhadap aktivitas enzim yang terlibat dalam proses fotosintesis dan respirasi.

Tanaman kelapa merupakan komoditi ekspor dan dapat tumbuh disepanjang pesisir pantai khususnya, dan dataran tinggi serta lereng gunung pada umumnya. Buah kelapa yang menjadi bahan baku minyak disebut kopra, dimana kandungan minyaknya berkisar antara $60-65 \%$. Sedang daging buah segar (muda) kandungan minyaknya sekitar $43 \%$. Minyak kelapa terdiri dari gliserida, yaitu senyawa antara gliserin dengan asam lemak. Kandungan asam lemak dari minyak kelapa adalah asam lemak jenuh yang diperkirakan $91 \%$ terdiri dari Kaproat, kaprilat, kaprat, laurat, miristat, Palmatic, stearat, arachidic, dan asam lemak tak jenuh sekitar $9 \%$ yang terdiri dari Oleat dan Linoleic (Warisno, 2003).

Salah satu produk dari hasil olahan kelapa yang mempunyai nilai jual tinggi adalah minyak murni atau virgin coconut oil (VCO). Minyak kelapa murni, atau lebih dikenal dengan Virgin Coconut Oil (VCO), adalah modifikasi proses pembuatan minyak kelapa sehingga dihasilkan produk dengan kadar air dan kadar asam lemak bebas yang rendah, berwarna bening, berbau harum, serta mempunyai daya simpan yang cukup lama yaitu lebih dari 12 bulan. Virgin coconut oil mengandung asam laurat $\mathrm{CH} 3(\mathrm{CH} 2) 10 \mathrm{COOH} 50 \%$ dan asam kaprilat $\mathrm{CH} 3(\mathrm{CH} 2) 6 \mathrm{COOH} 7 \%$. Kedua asam ini merupakan asam lemak jenuh rantai sedang yang mudah dimetabolisir dan bersifat anti mikroba. Di dalam tubuh, asam laurat menjadi monolaurin, sedangkan asam kaprilat menjadi monokaprin (Sutarmi, 2006). Asam laurat mempunyai fungsi, yakni diubah menjadi monolaurin di dalam tubuh manusia. Monolaurin adalah monogliserida antiviral, antibakteri dan antiprotozoal yang digunakan oleh sistem kekebalan manusia dan hewan untuk menghancurkan virus-virus pelindung lemak, seperti HIV, herves, influenza berbagai bakteri patogen. Asam kaprat yang juga berfungsi sebagai zat kekebalan tubuh ketika diubah menjadi monokaprin di dalam tubuh manusia atau hewan. Monokaprin memiliki efek antiviral terhadap HIV dan herpen simplex serta bakteri yang tertular melalui hubungan seks (Novarianto, 2007). Menurut Barlina dkk. (2006) Kandungan utama VCO adalah asam laurat dan asam kaprat, asam ini dalam tubuh manusia diubah menjadi monolaurin dan monocaprin yang bersifat anti virus, anti bakteri dan anti jamur. Manfaat VCO menurut Wibowo (2006) dan Barlina dkk. (2006) antara lain sebagai suplemen pada makanan, kosmetik, dan farmasi (obat-obatan).

Dengan melihat banyaknya manfaat dari minyak VCO ini, maka tim pelaksana PKM yaitu para dosen yang terdiri dari beberapa lintas fakultas yang ada di Universitas Muhammadiyah Mataram telah mengadakan kegiatan pengabdian yang bertujuan untuk melatih para perempuan di desa Dangiang Kabupaten Lombok Utara yang merupakan salah satu desa terdampak bencana gempa pada tahun akhir 2018 lalu. Kegiatan pelatihan ini bertujuan untuk mengajarkan dan melatih para perempuan untuk memiliki ketrampilan akan pemanfaatan yang lain dari hasil olahan kelapa agar lebih untuk mengembangkan semua potensi yang dimiliki desa untuk pertumbuhan dan perkembangan penghasilan masyarakat selanjutnya.

Pemberdayaan perempuan untuk memiliki pengetahuan dan ketrampilam dalam memahami manfaat sumber daya alam yang dalam hal ini kelapa yang banyak ditanam oleh 
masyarakat di desa ini merupakan langkah awal membangun masyarakat lebih cepat membenahi kondisi kesejahteraan dan menambah pendapatan atau penghasilan (income) bagi keluarga untuk mempercepat pemulihan ekonomi masyarakat yang terdampak bencana gempa bumi yang berkekuatan 7 skala richter di akhir tahun 2018 tersebut telah meluluhlantakkan kondisi perekonomian masyarakat. Dengan harapan pengetahuan yang didapat ditularkan pada lingkungan sekitar melalui pelatihan pembuatan minyak VCO. Pada kegiatan tersebut, akan diberikan pemaparan mengenai penjelasan dengan memberikan pengetahuan akan ketrampilan cara pengolahan dan pembuatan minyak VCO ini melalui presentasi dan pemberian contoh-contoh ujicoba yang telah dilakukan sebelumnya oleh tim pengabdian, kegiatan ini kemudian dilanjutkan dengan sesi tanya jawab dan quiz mengenai materi pelatihan ini untuk melihat dan mengetahui sejauh mana mereka dapat mempraktekkannya setelah kegiatan ini berlangsung di dusun mereka masing-masing dengan menularkan kepada para perempuan di sekitarnya.

\section{METODE}

Kegiatan pengabdian kepada masyarakat (PKM) ini telah dipersiapkan dalam beberapa pekan yang dimulai dari kegiatan observasi, interview langsung pada masyarakat di beberapa desa terdampak bencana gempa di Kabupaten Lombok Utara sebelum akhirnya memutuskan pelaksanaannya di Desa Dangiang yang dilakukan selama 8 (hari) dengan melihat sumber daya alam yang menjadi faktor pendukung dari pemilihan desa yang menjadi tempat sasaran kegiatan PKM ini. Tim PKM dalam pelaksanaannya dapat dikatakan menggunakan metode observasi partisipatoris atau observasi partisipan adalah suatu proses pengamatan yang dilakukan oleh observer dengan ikut terlibat langsung atau dengan mengambil bagian dalam kehidupan orang-orang yang akan diobservasi, dan dilanjutkan dengan metode praktik, dimana definisi dari metode ini adalah metode yang dilakukan oleh tim pengabdian dengan cara melakukan kegiatan secara langsung dengan mempraktekkan apa yang akan diberikan pada PKM ini yang dalam hal ini seperti pembuatan minyak VCO yang sebelumnya juga sebelum kegiatan ini dipraktekkan di masyarakat, maka tim melakukan ujicoba terlebih dahulu pada beberapa jenis dan ukuran juga masa kelapa untuk mampu memberikan praktek dengan beberapa contoh hasil dari jenis kelapa dan sebagainya yang nantinya menjadi contoh langsung, sehingga penyajian materi dengan memberikan penjelasan melalui presentasi power point cukup menjadi pengantar sebelum kegiatan pelatihan pembauatan minyak VCO ini dilakukan secara bersama para perempuan yang ada di desa Dangiang Kabupaten Lombok Utara ini.

Dalam pelaksanaan kegiatan pengabdian pada masyarakat ini tim pelaksana pengabdian pada masyarakat ini bermitra dengan para perempuan yang ada di Desa Dangiang Kabupaten Lombok Utara dengan melibatkan ibu-ibu dan remaja putri sekitar 25 orang dari beberapa dusun yang ada di desa ini yang merupakan perwakilan dusun, yang selanjutnya nanti merekapun akan membuat pelatihan kembali di dusun mereka masingmasing dimana tim pengabdian juga memberikan kelengkapan alat-alat untuk membuat pelatihan minyak VCO ini. Di bawah ini adalah tahapan pelaksanaan kegiatan pengabdian pada masyarakat yang dilaksanakan oleh tim pelaksanan pengabdian yang terdiri dari kolaborasi antara para dosen dan mahasiswa yang tergabung dalam Komunitas Relawan Muhammadiyah yang juga tergabung dalam Muhammadiyah Disaster Management Centre (MDMC) Nusa Tenggara Barat.

Gambar 1 menunjukkan tahapan dari pelaksanaan kegiatan teknis yang dilaksanakan dalam kegiatan PKM :

1. Pelaksanaan survei dan observasi menjadi tahapan pertama dalam pelaksanaan kegiatan PKM ini, dimana tujuan dari kedua kegiatan tersebut adalah untuk melihat desa mana yang dapat djadikan sebagai sasaran dari kegiatan ini yang tentunya memperhatikan sumber daya alam yang lebih potensial yang ada di desa-desa di wilayah terdampak bencana gempa di akhir tahun 2018 lalu, yang bertujuan untuk memberikan ketrampilan untuk segera dapat melakukan percepatan peningkatan kesejahteraan masyarakat khususnya para perempuan agar dapat memiliki tambahan pengahasilan yang diakibatkan saat bencana itu telah menyebabkan penghasilan masyarakat belum normal dan pulih kembali.

2. Surat menyurat khususnya perijinan kepada pihak desa, ibu-ibu PKK, kelompok remaja putri yang ada di dususn-dusun desa Dangiang terkait waktu dan jadwal kegiatan pengabdian pada masyarakat ini yang mana pelaksanaan kegiatan.

3. Melakukan presentasi sebelum pelaksanaan praktek pembuatan dalam pelatihan tersebut agar masyarakat memiki pengetahuan awal tentang manfaat dan sebagainya tentang minyak 
VCO ini yang dalam pelaksanaan kegiatan ini para dosen yang merupakan tim pengabdian juga dibantu oleh para mahasiswa yang termasuk dalam Komunitas Relawan Muhammadiyah yang juga tergabung dalam Muhammadiyah Disaster Management Center (MDMC) Nusa Tenggara Barat.

4. Melakukan pelatihan selama 8 hari pada beberapa pekan dengan melakukan praktek langsung pada ibibu dan emaja putri sbagai partisipan dalam kegiatan pelatihan ini.

5. Dan melakukan evaluasi terhadap pelaksanaan Pelatihan dengan meminta langsung pada partisipan tersebut untuk melihat keberhasilan target yang diharapkan dalam kegiatan PKM ini.

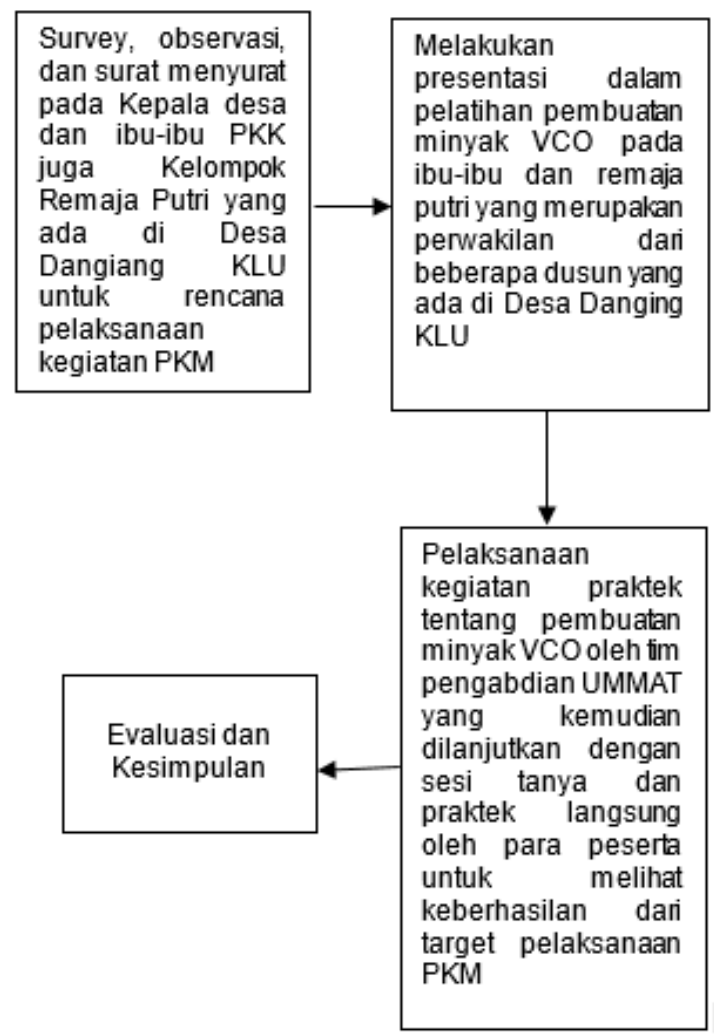

Gambar 1. Tahap Pelaksanaan Kegiatan PKM

\section{HASIL DAN PEMBAHASAN}

Kelapa (Cocos nucifera $L$ ) merupakan salah satu hasil pertanian Indonesia yang cukup potensial. Hampir semua bagian dari tanaman tersebut dapat dimanfaatkan. Banyak kegunaan yang dapat diperoleh dari kelapa dan salah satu cara untuk memanfaatkan buah kelapa adalah mengolahnya menjadi minyak makan atau minyak goreng. Produk kelapa yang paling berharga adalah minyak kelapa, yang dapat diperoleh dari daging buah kelapa segar atau dari kopra (Suhardiyono, 1995). Buah kelapa (cocos nucifera) termasuk family palmae dari genus cocos. Pohon kelapa mempunyai tinggi ratarata 12,3 meter dan sejak ditanam sampai berbuah hingga siap dipetik pohon kelapa membutuhkan waktu 12 bulan (Suhardiyono,1993). Pada dasarnya dikenal dua varietas kelapa, yaitu varietas Nana yang umum disebut kelapa genjah dan varietas Typica yang umum disebut kelapa dalam. Kelapa genjah berdasarkan sifatnyadibagi 5 yaitu kelapa gading, kelapa raja, kelapa puyuh, kelapa raja malabr, kelapa hias. Kelapa dalam berdasarkan sifatnya dibagi 6 yaitu : kelapa hijau, kelapa merah, kelapa manis, kelapa bali, kelapa kopyor, kelapa lilin (Wahyuni, Mita, Ir., 2000).

Buah kelapa terdiri dari bagian-bagian seperti:

1. Epicarp (Kulit Luar) yaitu kulit bagian luar yang berwarna hijau, kuning, atau jingga permukaannya licin, agak keras dan tebalnya $0,14 \mathrm{~mm}$.

2. Mesocarp (Sabut) yaitu kulit bagian tengah yang disebut serabut terdiri dari bagian berserat tebalnya $35 \mathrm{~mm}$.

3. Endocarp (Tempurung) yaitu bagian tempurung yang keras sekali tebalnya 3 $5 \mathrm{~mm}$, bagian dalam melekat pada kulit luar biji.

4. Testa (Kulit Daging Buah ) yaitu bagian dari warna kuning sampai coklat.

5. Endosperm (Daging Buah ) yaitu bagian yang berwarna putih dan lunak, sering disebut daging kelapa yang tebalnya $810 \mathrm{~mm}$.

6. Air Kelapa yaitu bagian yang berasa manis, mengandung mineral $4 \%$, gula $2 \%$, dan air.

7. Lembaga yaitu bakal tanaman setelah buah tua (Palungkun, Rony ,1993)

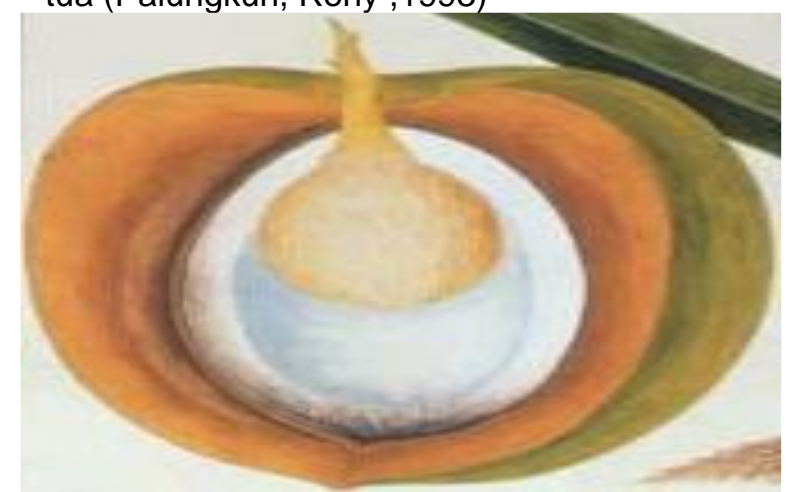

Gambar 2. Bagian - Bagian Kelapa

Dikenal memiliki banyak kandungan alami untuk tubuh dan ramah tanpa efek samping ketika pemakaian, Virgin Coconut Oil (VCO) seketika menjelma menjadi primadona baru di dunia kesehatan dan kecantikan di Indonesia bahkan di dunia. Maka, tak heran jika banyak negara mulai ikut memproduksi secara besar-besaran jenis minyak ini untuk mencukupi kebutuhan dan keinginan pasar. 
Berdasarkan pemaparan ini, maka dapat dikatakan bahwa kelapa yang merupakan sumber daya alam yang banyak dijumpai di daerah-daerah perbukitan, pesisir dan pegunungan seperti yang banyak dijumpai di wilayah Kabupaten Lombok Utara telah menginspirasi tim pengabdian untuk menjadikan kelapa sebagai obyek pengabdian kepada masyarakat dengan memberikan pengetahuan dan ketrampilan pada masyarakat dengan memberikan pemahaman tentang banyaknya manfaat dan hasil olahan yang dapat dihasilkan dari kelapa. Adapun kegiatan PKM yang telah dilakukan oleh tim pengabdian para dosen UMMAT yang bekerjasama dengan mahasiswa dan MDMC NTB ini kemudian difokuskan pada pelatihan pembuatan minyak Virgin Coconut Oil (VCO) atau minyak murni yang dewasa ini amat sangat banyak dibutuhkan dan telah banyak dibuat pula oleh beberapa produsen besar untuk keperluan industri dan sebagainya bahkan pengobatan..

Pembuatan minyak kelapa murni ini memiliki banyak keunggulan, yaitu:

a. tidak membutuhkan biaya yang mahal, karena bahan baku mudah didapat dengan harga yang murah

b. pengolahan yang sederhana dan tidak terlalu rumit, serta

c. penggunaan energi yang minimal, karena tidak menggunakan bahan bakar, sehingga kandungan kimia dan nutrisinya tetap terjaga terutama asam lemak dalam minyak.

Tujuan dari kegiatan PKM ini adalah untuk memberika pengetahuan dan ketrampilan akan banyaknya manfaat dari pengolahan sumber daya alam seperti kelapa yang notabene di desa Dangiang ini menjadi komoditi yang potensial dan harga juga dapat dijangkau dengan banyaknya masyarakat yang menanam di kebun dan pekarangan rumah mereka yang banyak diliahat dan dijumpai tim PKM selama kegiatan survey dan observasi sebelum pelaksanaan pelatihan pembuatan minyak VCO ini. Jika dibandingkan dengan minyak kelapa biasa, atau sering disebut dengan minyak goreng (minyak kelapa kopra), minyak kelapa murni mempunyai kualitas yang lebih baik. Minyak kelapa kopra akan berwarna kuning kecoklatan, berbau tidak harum, dan mudah tengik, sehingga daya simpannya tidak bertahan lama (kurang dari dua bulan).

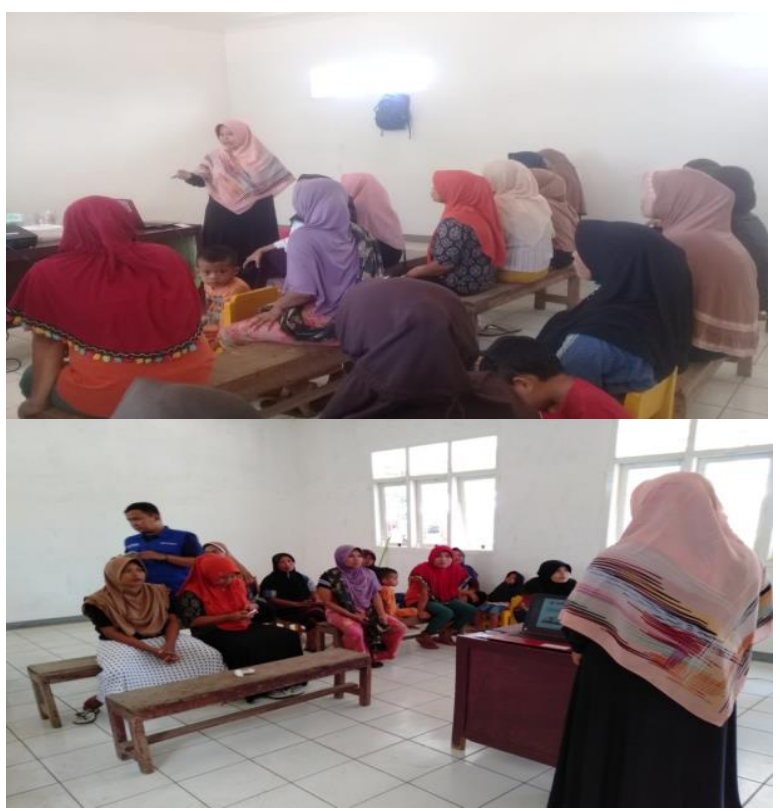

Gambar 3. Proses transfer ilmu pengetahuan melalui presentasi kegiatan pelatihan pembuatan minyak VCO di Desa Dangiang Kabupaten Lombok Utara

Dari segi ekonomi, minyak kelapa murni mempunyai harga jual yang lebih tinggi dibanding minyak kelapa kopra, sehingga studi pembuatan VCO perlu dikembangkan dan itu dapat dilakukan oleh masyarakat desa yang di daerah mereka banyak komoditi kelapa ini. Pada dasarnya, cara pembuatan VCO tak berbeda jauh dengan cara pembuatan minyak kelapa sawit, minyak sayur, atau minyak palem (palma) yaitu memeras atau mengekstraksi buah kelapa hingga ke tetesan terakhir minyak yang dihasilkan. Perbedaannya terletak pada metode ekstraksi VCO yang diproses dengan tehnik cold-pressed tanpa melibatkan adanya panas, baik panas dari kompor ataupun panas matahari. Proses ini menghasilkan varian terbaik dari minyak kelapa untuk kesehatan Anda. Namun, perlu dicatat bahwa tidak semua VCO dibuat dengan menggunakan teknik ini. VCO juga dipercaya memiliki kandungan medium-chain triglycerides (MCT) yang dipercaya dapat memicu "kolesterol baik" sehingga baik untuk jantung kita 


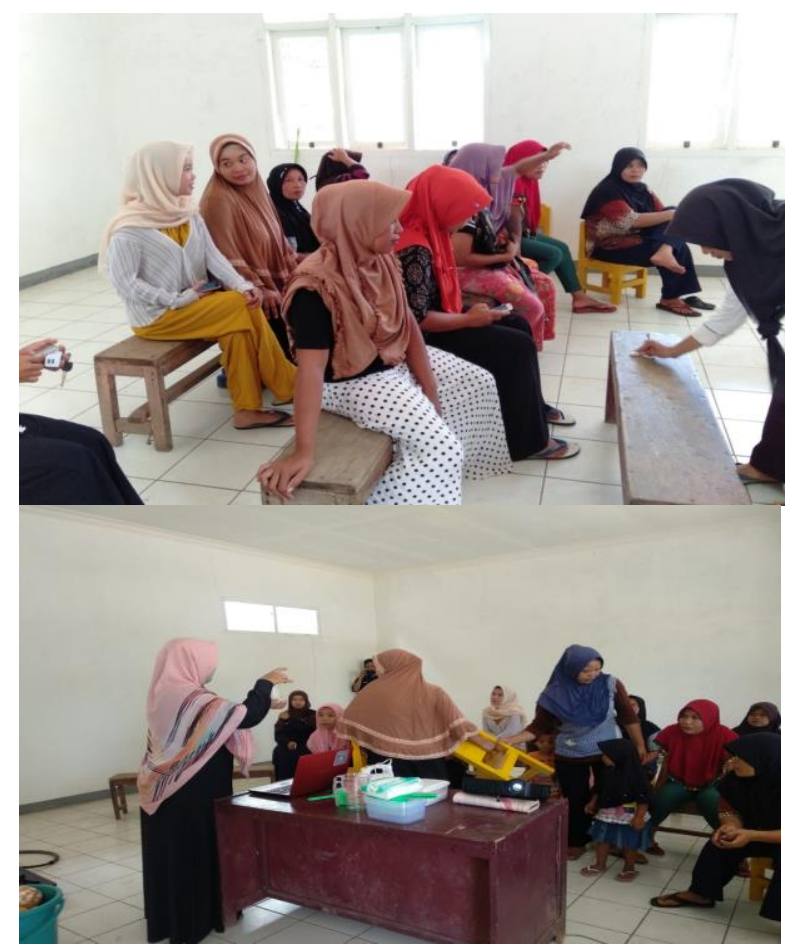

Gambar 4. Kegiatan sesi tanya jawab dan dilanjutkan praktek oleh tim PKM

Proses pembuatan minyak kelapa murni secara umum dapat dijelaskan sebagai berikut : a. Kelapa dikupas dengan cara memisahkan antara daging buah dengan kulit sabut dan tempurungnya, lalu airnya dibuang. Kelapa yang sudah dikupas ditempatkan di dalam satuwadah dan siap untuk diparut.

b. Kelapa diparut dan dikumpulkan dalam wadah yang cukup besar, agar hasil parutan tidak berhamburan.

c. Parutan kelapa dicampur dengan air bersih, lalu diperas. Hasil perasan kelapa ditampung didalam toples plastik. Proses pemerasan kelapa ini dilakukan dua kali. Jadi, ampas hasil perasanpertama dicampur lagi dengan air bersih, lalu diperas dan hasil perasan disaring dan ditampungdi dalam toples plastik. Proses pemerasan ini sangat penting dan harus segera dilakukan, karenajika hasil parutan kelapa terlalu lama didiamkan rasanya akan asam dan tidak bisamenghasilkan VCO.

d. Air hasil perasan yang ada di toples plastik didiamkan sekitar 2 jam, sehingga terdapat 2 lapisanlapisan atas adalah kanil (krim) dan bagian bawah adalah air ( skim )

e. Setelah air terbuang, proses selanjutnya kanil (krim) dapat diolah dengan berbagai metode yaitu sentrifugasi, pancingan, pengasaman, fermentasi, dan enzimatis.

f. Selanjutnya akan terbentuk tiga lapisan. lapisan pertama berada paling bawah adalah air, lapisan kedua berada ditengah adalah blondo dan lapisan ketiga yang paling atas minyak.

g. Minyak yang berada di lapisan atas adalah minyak VCO, karena itu harus ditampung di tempatbersih dan hieginis (toples plastik atau lainnya). Cara mengambil minyak dengan memasukkanselang kecil, lalu disedot dan ditampung dalam wadah yang telah disiapkan.

h. Untuk menghindari masuknya bakteri dan membuang kadar air, lakukan penyaringan. Penyaringan ini sangat penting agar selain kadar air bisa mencapai 0,015\%, juga supaya minyaktidak berbau tengik. berwarna putih. Keberadaan air ini akan mempercepat proses ketengikan. Selain itu, gumpalan tersebut kemungkinan juga merupakan komponen blondo yang tidak tersaring semuanya. Kontaminasi seperti ini secara langsung akan berpengaruh terhadap kualitas VCO (Adopsi dari Setiaji, $B$ dan Surip, $P, 2006)$.

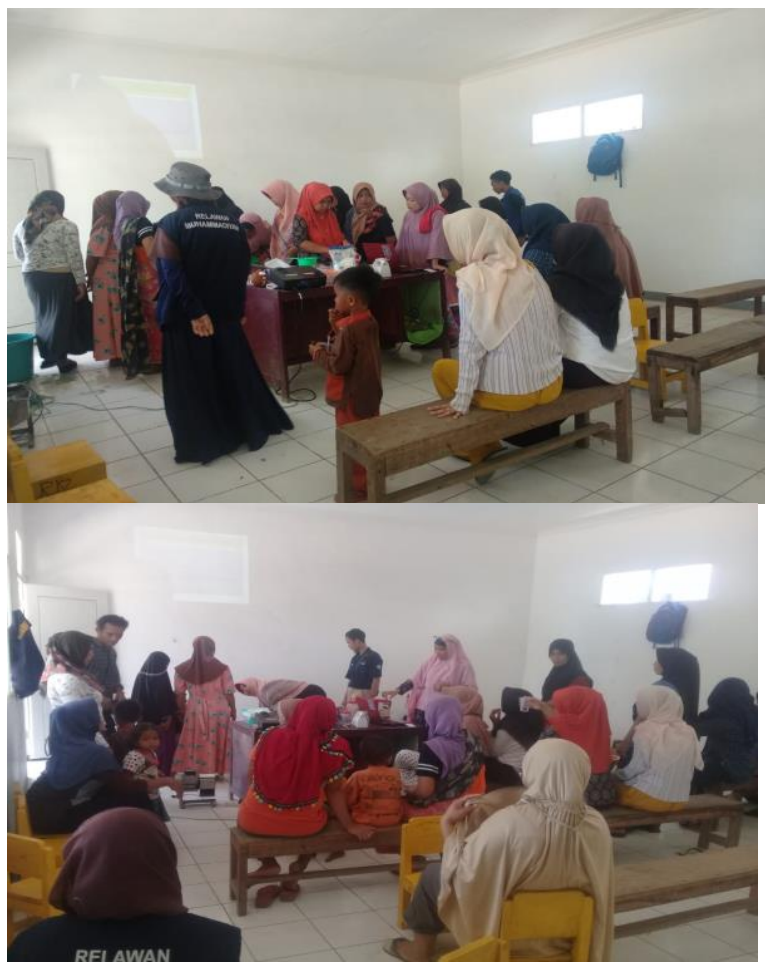

Gambar 5. Praktek pengolahan dan pembuatan minyak VCO oleh masyarakat

VCO sangat kaya dengan kandungan asam laurat (laurat acid) berkisar 5070\%. Di dalam tubuh manusia asam laurat akan diubah menjadi monolaurin yang bersifat antivirus, antibakteri dan antiprotozoa serta asamasam lain seperti asam kaprilat, yang didalam tubuh manusia diubah menjadimonocaprin yang bermanfaat untuk penyakit yang disebabkan oleh virus HSV2dan HIV1 dan bakteri neisseria gonnorhoeae. Virgin Coconut Oil juga tidak membebani kerja pankreas serta dalam energi 
bagi penderita diabetes dan mengatasi masalah kegemukan/obesitas. Oleh karena pemanfaatannya yang cukup luas, maka dengan pembuatan minyak kelapa murni ini dapat menjadi salah satu obat alternatif, selain itu juga dapat meningkatkan nilai ekonomi (anonim, 2009).

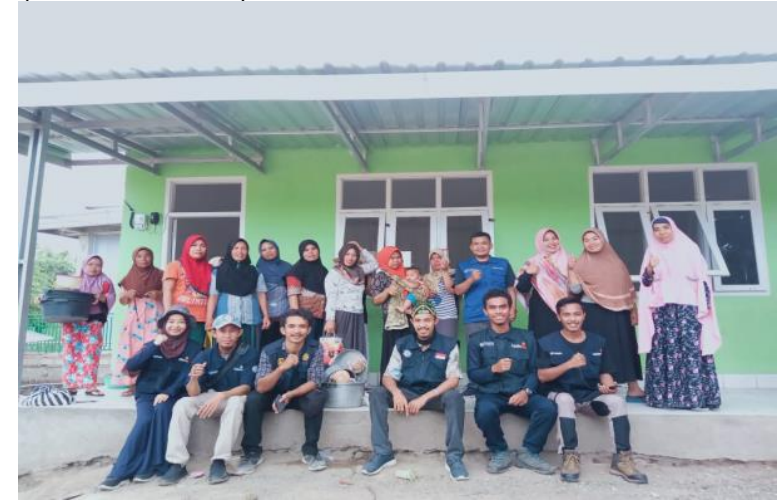

Gambar 5. Tim Pengabdian Kepada Masyarakat (PKM UMMAT)

Dalam kegiatan PKM ini, para tim pengabdian terakhir melakukan evaluasi untuk melihat sejauh mana keberhasilan akan target pencapaian yang dilakukan dengan melaksanakan praktek di lapangan dengan menggunakan beberapa peralatan sederhana seperti baskom, heler kelapa, saringan dan beberapa alat na bahan khususnya kelapa yang cocok dipakai dalam pengolahan dan pembuatan minyak VCO ini yang sudah diberikan dalam pemaparan materi dalam dua kali pertemuan. Kegiatan ini paling disenangi partisipan atau peserta PKM karena mereka bisa aktif berpartisipasi dan melakukan praktek langsung dalam kegiatan ini bersama tim, pendamping dan mahasiswa. Sehingga dapat dikatakan dengan kegiatan pelatihan pembuatan minyak VCO ini diharapkan agar peserta dapat mengembangkan semua potensi yang dimiliki desa dan melekatkan dasar kearah perkembangan sikap, pengetahuan, ketrampilan dan daya cipta untuk menyesuaikan diri dengan lingkungannya dan untuk pertumbuhan dan perkembangan kondisi ekonomi selanjutnya. Pemberdayaan perempuan untuk memahami cara pengolahan ini merupakan langkah awal membangun masyarakat sadar dan segera mempersiapkan diri untuk segera bangkit menata kondisi ekonomi sehingga dapat memulihkan kesejahteraan masyarakat dan pastinya menambah penghasilan atau pendapatan (income) bagi para perempuan untuk membantu para suami dalam mencari nafkah dan menghidupi perekonomian keluarga.

\section{SIMPULAN DAN SARAN}

Bencana gempa yang pernah terjadi pada akhir tahun yaitu sekitar bulan Juli sampai dengan bulan Nopember tahun 2018 lalu di pulau Lombok dengan kekuatan 7 skala richter yang mengakibatkan banyaknya korban jiwa dan harta tersebut telah menginisasi tim pelaksana pengabdian kepada masyarakat mengadakan pelatihan pembuatan minyak VCO dengan melibatkan para dosen lintas prodi/fakultas dan mahasiswa yang termasuk dalam Komunitas Relawan Muhammadiyah yang juga tergabung dalam Muhammadiyah Dissaster Management Centre (MDMC) Nusa Tenggara Barat yang bertujuan untuk memberikan pengetahuan dan ketrampilan bagi para perempuan di desa Dangiang yang terdiri dari ibu-ibu dan remaja putri yang berasal dari beberapa dusun yang menjadi partisipan dalam kegiatan pelatihan ini.

Pembuatan minyak kelapa murni ini memiliki banyak keunggulan yaitu tidak membutuhkan biaya yang mahal karena bahan baku mudah didapat dengan harga yang murah, pengolahan yang sederhana dan tidak terlalu rumit, serta penggunaan energi yang minimal karena tidak menggunakan bahan bakar sehingga kandungan kimia dan nutrisinya tetap terjaga terutama asam lemak dalam minyak. Jika dibandingkan dengan minyak kelapa biasa atau sering disebut dengan minyak goreng (minyak kelapa kopra) minyak kelapa murni mempunyai kualitas yang lebih baik. Minyak kelapa kopra akan berwarna kuning kecoklatan, berbau tidak harum dan mudah tengik sehingga daya simpannya tidak bertahan lama (kurang dari dua bulan). Dari segi ekonomi minyak kelapa murni mempunyai harga jual yang lebih tinggi dibanding minyak kelapa kopra sehingga studi pembuatan VCO perlu dikembangkan.

Simpulan yang kemudian dapat ditarik setelah kegiatan PKM ini terlaksana adalah sebagai berikut:

a) dimilikinya pengetahuan dan pemahaman yang merupakan upaya pemberdayaan bagi para perempuan di desa ini agar memiliki ketrampilan dalam pengolahan kelapa khususnya pembuatan minyak VCO, dan

b) memberikan ketrampilan yang lebih akan pemanfaatan sumber daya alam agar menjadi tambahan penghasilan atau mampu meningkatkan pendapatan (income) yang cukup potensial sebagai langkah awal membangun masyarakat yang berdayaguna.

Sedangkan saran yang dapat diberikan untuk perbaikan dan kemaslahatan bersama kedepan adalah hendaknya memang telah menjadi tugas dan tanggungjawab para tenaga 
ahli yang dalam hal ini pemerintah untuk selalu dapat mensosialisaikan dan memberikan pengetahuan dan pemahaman pada masyarakat khususnya di pulau Lombok dan Provinsi Nusa Tenggara Barat akan pentingnya sebuah mekanisme tindakan dalam mengolah dan pemanfaatan sumber daya alam yang dapat dijadikan sebagai nilai tambah dan mampu meningkatkan penghasilan dalam ercepatan pemulihan kondisi ekonomi masyarakat. Oleh karena itu, kegiatan pelatihan ini sangat perlu dilakukan secara simultan dan berkelanjutan agar masyarakat menjadi berdayaguna melalui pemberdayaan masyarakat.

\section{DAFTAR RUJUKAN}

B Rindengan, S Karouw, R. H. (2009). Minyak kelapa murni (virgin coconut oil): pengolahan, pemanfaatan dan peluang pengembangannya. Monograf Pasca Panen Kelapa, 9-19.

Dikti, D. (2017). Buku Panduan Pelaksanaan Penelitian dan Pengabdian Kepada Masyarakat Edisi XI Tahun 2017.

Karunia, K. A. (n.d.). PENGARUH KETINGGIAN TEMPAT (SUHU) TERHADAP PERTUMBUHAN TANAMAN, TERNAK, HAMA, PENYAKIT TUMBUHAN, DAN GULMA. 2010. Retrieved November 9, 2020, from http://aredhieanverne.blogspot.com/2010/ 12/pengaruh-ketinggian-tempatsuhu.html

Mataram, L. U. (2018). Pedoman Pengabdian Kepada Masyarakat dan Prosedur Penulisan Proposal. Universitas Muhammadiyah Mataram.

NOVARIANTO, H., \& TULALO, M. (2020). KANDUNGAN ASAM LAURAT PADA BERBAGAI VARIETAS KELAPA SEBAGAI BAHAN BAKU VCO. Jurnal Penelitian Tanaman Industri. https://doi.org/10.21082/jlittri.v13n1.2007. 28-33

Palungkun, R. (1993). Aneka Produk Olahan Kelapa. Swadaya.

Perindustrian, D. (1986). Mutu dan Cara Uji Minyak Kelapa.

Rindengan, B., dan Hengky, N. (2004). Pembuatan \& Pemanfaatan Minyak Kelapa Murni. Swadaya.

Setiaji, B. dan S. P. (2006). Membuat VCO Berkualitas Tinggi. Swadaya.

Suhardiyono, L. (1993). Tanaman Kelapa Budidaya dan Pemanfaatannya. Kanisius.

Sutarmi, R. (2006). Taklukkan Penyakit dengan VCO (Virgin Coconut Oil). Swadaya.

Warisno. (2003). Budidaya Kelapa Genjah. Kanisius. 